\title{
Standardization of solvent extraction process for Lycopene extraction from tomato pomace
}

\begin{abstract}
Tomato skins can be a viable source of lycopene. Industrial production of lycopene from tomatoes appears to be in high demand by food companies for the development of functional foods. Majority of companies that are into the business of manufacturing fruit extracts, prefer conventional solvent extraction method. Solvent extraction is extremely efficient with carotenoids (lycopene and $\beta$-carotene) with a total of carotenoids recovery of $96 \%$. The optimization of the solvent extraction process for the maximum recovery of lycopene from tomato pomace was carried out by selecting the suitable solvent system, temperature-time combination and feed to solvent ratio, i.e. Acetone: Ethyl acetate $(1: 1), 40^{\circ} \mathrm{C} / 5 \mathrm{hr}$ and $1: 30(\mathrm{w} / \mathrm{v})$. The maximum lycopene was extracted using optimized solvent extraction process and had the lycopene content $611.105 \mathrm{mg} / 100 \mathrm{~g}$, refractive index 1.37604 and colour value $5.59 \mathrm{~L}^{*}, 8.00 \mathrm{a}$, $6.14 \mathrm{~b}^{*}$. The storage of lycopene extract at refrigerated condition was found safe for maintaining its lycopene content. There was just $2.6 \%$ reduction in lycopene content after 60 days of storage at refrigerated condition.
\end{abstract}

Keywords: lycopene extract, solvent extraction, standardization, tomato pomace

\author{
Volume 2 Issue I - 2017
}

\author{
Dipen Pandya, Sanjay Akbari, Hiren Bhatt, \\ Joshi DC \\ Anand Agricultural University, India
}

\begin{abstract}
Correspondence: Dipen Pandya, College of Food Processing Technology and Bio-Energy, Anand Agricultural University,
\end{abstract} Anand-388 I I0, India, Email dipen.pandyal I@gmail.com

Received: October 26, 2016 | Published: January 25, 2017
Abbreviations: SE, solvent extraction; SCFE, super critical fluid extraction

\section{Introduction}

Tomato (Lycopersicon esculentum) is used mainly as a vegetable both in fresh as well as in processed forms, in food preparations. More than $80 \%$ of processed tomatoes produced are consumed in the form of tomato juice, paste, puree, ketchup and sauce. Lycopene is an important carotenoid in tomatoes, responsible for the red color of tomatoes. ${ }^{1}$ Tomatoes and tomato products are the major sources of lycopene compounds which can represent more than $85 \%$ of all the carotenoids present in the fruits. The antioxidant capability of lycopene has led to promising results in decreasing the risk of some illness and cancers. ${ }^{2,3}$ Animals and humans do not synthesize lycopene and thus depend on dietary sources. Tomato skins can be a viable source of lycopene, as the per unit mass of tomato skins contain about five times more lycopene than the whole tomato pulp. Considering that more than one third of the tomatoes delivered to processing plants end as processing wastes, mainly constituted by seeds and skins, the recovery of this carotenoid could represent an alternative for the valorization of the by-products of the tomato industry. ${ }^{4}$ Byproducts and waste materials from the food processing industry can be a money-spinner if they are appropriately utilized using newer knowledge and technologies. ${ }^{5}$ Commercial processing of tomato produces a large amount of waste at various stages and constitutes the major part of the waste that comes from the pulper. ${ }^{6}$ The wet pomace contains $33 \%$ seed, $27 \%$ skin and $40 \%$ pulp. ${ }^{7}$ Most of the lycopene $(72-92 \%)$ is associated with the water-insoluble fraction and the skin. Therefore, skin extracts are especially rich in Lycopene. ${ }^{8}$

Presently, pomace (peels and seeds) in tomato industry is mechanically removed and discarded and is used for animal feed but it is not used for human consumption. It has high moisture content and incurs a drying expense in order to be preserved. Thus large quantity of carotenoids is lost as waste in tomato processing. Industrial production of lycopene from tomatoes appears to be in high demand by food companies for the development of functional foods. ${ }^{9}$ High-purity lycopene can be obtained from tomato fruits by various purification and separation processes including solvent extraction (SE), super critical fluid extraction (SCFE), distillation, membrane separation, chromatography and crystallization. The solvent extraction process is also a well established and well known technology. This type of extraction is extremely efficient with non-polar carotenoids (lycopene and $\beta$-carotene) with a total of carotenoids recovery of $96 \% .^{10}$ Successful extraction technology for lycopene recovery from tomato pomace can significantly improve the economic aspects of tomato industry besides making available one of the most potent antioxidants for formulating health supplements for human beings.

\section{Materials and methods}

\section{Solvent extraction of lycopene from tomato pomace}

Fresh tomato pomace having $80-85 \%$ moisture content (w.b.) was procured in bulk from a nearby Tomato processing industry, $\mathrm{M} / \mathrm{s}$ Nirmal Foods Pvt Ltd, Ta: Virsad (Anand), Gujarat. The pomace was bagged and stored at $-20^{\circ} \mathrm{C}$ in deep freezer (Figure 1) until used for further analysis and experiments. The pomace sample was drowned from deep freezer and then allowed to thaw for 120min before analysis and experiments. The extraction of lycopene from tomato pomace using Shaker water bath was carried out by placing $5 \mathrm{~g}$ (approx.) weighed sample into iodine flask containing $150 \mathrm{ml}$ of solvent system and then placing it on the flask rack of shaker water bath maintained at required temperature-time combination. The extract was then analyzed for its lycopene content using UV-Vis spectroscopy technique (Make: Varian-Carry-50). The remaining extract, was taken for measuring the lycopene content using UV-Vis spectrophotometer at $503 \mathrm{~nm} .{ }^{11-}$ ${ }^{13}$ The data were recorded and the lycopene content $(\mathrm{mg} / 100 \mathrm{~g})$ was calculated using the following formula: 

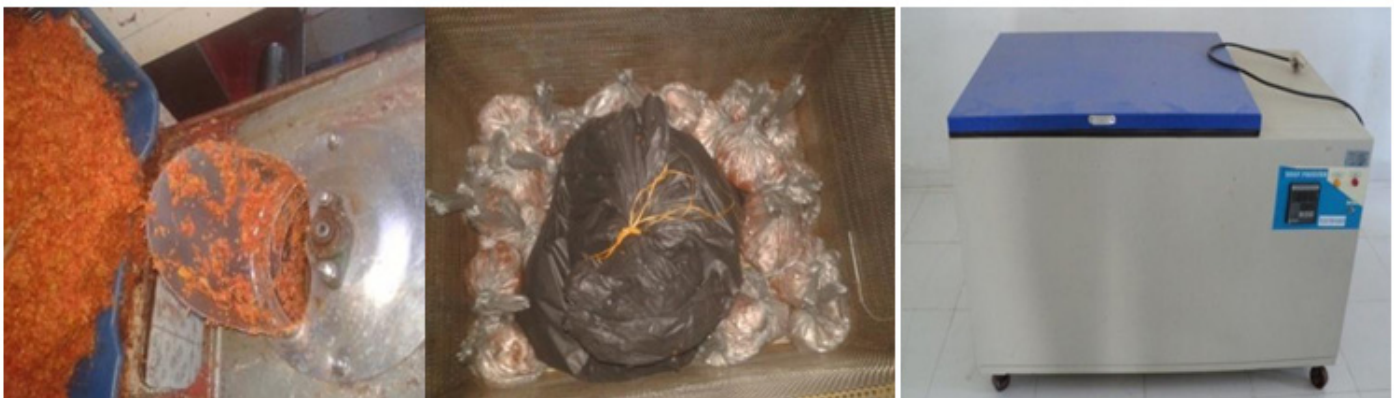

Figure I Fresh pomace bagged and stored at $-20^{\circ} \mathrm{C}$ in deep freezer

Lycopene content $=\frac{\mathrm{A}_{503}}{\mathrm{a} 503} \times \frac{\mathrm{V}}{1000} \times \frac{100}{\mathrm{w}}$

where,

$\mathrm{A}_{503}=$ absorbance noted at $503 \mathrm{~nm}$

$\mathrm{a}_{503}=$ specific extinction coefficient of lycopene in $\mathrm{n}$-hexane

$\mathrm{v}=$ total volume of solution, $\mathrm{ml}$

$\mathrm{w}=$ weight of pomace, $\mathrm{g}$

\section{Identification of suitable solvent system}

For identification of the suitable solvent system for efficient extraction of lycopene from tomato pomace, both polar and non-polar solvents were selected, i.e. acetone, ethanol, ethyl acetate, hexane and petroleum ether. Single solvent, double solvent system (1:1) and triple solvent systems (1:1:1) were used. Best solvent system was identified on the basis of highest percent lycopene recovery in tomato pomace sample.

\section{Optimization of the solvent extraction process}

For optimization of extraction process for maximum lycopene recovery from tomato pomace, solvent extraction was carried out using identified best solvent system at different temperature (30, 40 and $\left.45^{\circ} \mathrm{C}\right)$ and time $(1,5,10 \mathrm{~h})$ combinations. The best temperaturetime combination was identified on the basis of maximum per cent lycopene recovery measured using UV visible spectrophotometer. The identified best time-temperature combination was further used to optimize the feed to solvent ratio (1:10, 1:20 and 1:30) on the basis of percent lycopene recovery in the tomato pomace sample.

\section{Characterization of lycopene extract}

The characterization of the lycopene extracted using the optimized process was done using UV-Vis spectrophotometer, HPLC (Make: Varian, USA) for purity of lycopene in extract, lovibond colour measurement system and digital refractometer. Also, the sample was kept for its storage study for a period of 60days. Samples were filled in dark glass vials and stored at two different temperatures. One set was stored at $30^{\circ} \mathrm{C}$ temperature in an incubator (Make: Nova Instruments Pvt. Ltd., Ahmedabad) and other was stored in refrigerator at $-4 \pm 1^{\circ} \mathrm{C}$. The storage study was carried out for 60 days and samples were analyzed for its lycopene content at 6 intervals. The data obtained were analyzed statistically.

\section{Results and discussion}

\section{Identification of suitable solvent system}

The extract was analyzed for its lycopene content using UV-Vis Spectrophotometer. All the experiments were done in triplicates and average value is reported in Table 1 . The data were statistically analyzed using CRD. Identification of the suitable solvent system was done on the basis of the highest lycopene content present in the extract of tomato pomace sample. Among the twenty four different solvent systems used, solvent extraction carried out using Acetone: Ethyl acetate (T14) and Ethanol: Ethyl acetate (T15) gave significantly higher lycopene content than the other solvent systems. The lycopene extracted using T14 and T15 solvent system were found to be statistically at par and had the lycopene content, i.e. $7.91 \mathrm{mg} / 100 \mathrm{~g}$ and $8.02 \mathrm{mg} / 100 \mathrm{~g}$ respectively, in which the difference was found to be non-significant. Acetone-Ethyl acetate (T14) solvent system was selected because of the easy availability of both the solvents.

Table I Lycopene content found using different solvent systems

\begin{tabular}{llllll}
\hline Code & Solvent system & $\begin{array}{l}\text { Lycopene content in } \\
\text { extract }(\mathbf{m g} / \mathbf{l ~ 0 0 g})\end{array}$ & Code & Solvent system & $\begin{array}{l}\text { Lycopene content in } \\
\text { extract }(\mathbf{m g} / \mathbf{l ~ 0 0 g})\end{array}$ \\
\hline TI & Hexane & 0.54 & TI3 & Acetone: Ethanol & 3.52 \\
T2 & Petroleum ether & 0.48 & TI4 & Acetone: Ethyl acetate & 7.91 \\
T3 & Acetone & 3.79 & TI5 & Ethanol: Ethyl acetate & 8.02 \\
T4 & Ethanol & I.I5 & TI6 & $\begin{array}{l}\text { Hexane: Petroleum ether: } \\
\text { Acetone }\end{array}$ & 3.25 \\
T5 & Ethyl acetate & I.18 & TI7 & $\begin{array}{l}\text { Hexane: Petroleum ether: } \\
\text { Ethanol }\end{array}$ & 2.91 \\
T6 & $\begin{array}{l}\text { Hexane: Petroleum } \\
\text { ether }\end{array}$ & 0.52 & TI8 & $\begin{array}{l}\text { Hexane: Petroleum ether: } \\
\text { Ethyl acetate }\end{array}$ & 2.06 \\
\hline
\end{tabular}


Table Continued..

\begin{tabular}{|c|c|c|c|c|c|}
\hline Code & Solvent system & $\begin{array}{l}\text { Lycopene content in } \\
\text { extract }(\mathrm{mg} / \mathrm{l} 00 \mathrm{~g})\end{array}$ & Code & Solvent system & $\begin{array}{l}\text { Lycopene content in } \\
\text { extract }(\mathrm{mg} / \mathrm{l} 00 \mathrm{~g})\end{array}$ \\
\hline T7 & Hexane:Acetone & 1.25 & T19 & Hexane:Acetone: Ethanol & 5.59 \\
\hline T8 & Hexane: Ethanol & 3.14 & T20 & $\begin{array}{l}\text { Hexane:Acetone: Ethyl } \\
\text { acetate }\end{array}$ & 4.79 \\
\hline T9 & Hexane: Ethyl acetate & 1.08 & T2I & $\begin{array}{l}\text { Hexane: Ethanol: Ethyl } \\
\text { acetate }\end{array}$ & 6.24 \\
\hline TIO & $\begin{array}{l}\text { Petroleum ether: } \\
\text { Acetone }\end{array}$ & 1.65 & $\mathrm{~T} 22$ & $\begin{array}{l}\text { Petroleum ether:Acetone: } \\
\text { Ethanol }\end{array}$ & 2.88 \\
\hline TII & $\begin{array}{l}\text { Petroleum ether: } \\
\text { Ethanol }\end{array}$ & 2.75 & $\mathrm{~T} 23$ & $\begin{array}{l}\text { Petroleum ether: Ethanol: } \\
\text { Ethyl acetate }\end{array}$ & 3.28 \\
\hline $\mathrm{T} 12$ & $\begin{array}{l}\text { Petroleum ether: Ethyl } \\
\text { acetate }\end{array}$ & 1.05 & T24 & $\begin{array}{l}\text { Acetone: Ethanol: Ethyl } \\
\text { acetate }\end{array}$ & 6.76 \\
\hline
\end{tabular}

Optimization of the solvent extraction process for maximum lycopene recovery

Optimization of Temperature-Time combination: The optimum temperature-time combination was selected on the basis of the highest lycopene content $(\mathrm{mg} / 100 \mathrm{~g})$ from the tomato pomace sample. The lycopene extract was analyzed for its concentration using UV-Vis spectroscopy technique. Average value of lycopene content (mg/100g) of three replications is reported in Table 2. Among the nine different temperature-time combinations, extraction carried out at $40^{\circ} \mathrm{C} / 5 \mathrm{~h}$ and $40^{\circ} \mathrm{C} / 10 \mathrm{~h}$ had significantly higher lycopene recovery than the other temperature-time combinations. The amounts of lycopene extracted at $40^{\circ} \mathrm{C} / 5 \mathrm{~h}$ and $40^{\circ} \mathrm{C} / 10 \mathrm{~h}$, using Acetone-Ethyl acetate (T14) as the solvent system, were found to be statistically at par $(8.68 \mathrm{mg} / 100 \mathrm{~g}$ and $8.75 \mathrm{mg} / 100 \mathrm{~g}$ respectively). The temperature-time combination of $40^{\circ} \mathrm{C} / 5 \mathrm{~h}$ was selected as it saves both time of extraction and energy, hence reduces the cost of running the system to a great extent. The minimum lycopene recovery was observed at $45^{\circ} \mathrm{C} / 1 \mathrm{~h}$ extraction condition, i.e., $4.0 \mathrm{mg} / 100 \mathrm{~g}$. This may be due to the reduction in extraction power of solvent at higher temperature and the extraction time was also less.

Table 2 Effect of temperature-time combination on lycopene content

\begin{tabular}{llll}
\hline Factors & \multicolumn{3}{l}{ Time (t), hr } \\
\hline Temperature $(\mathbf{T}){ }^{\circ} \mathbf{C}$ & $\mathbf{I}$ & $\mathbf{5}$ & 10 \\
\hline 35 & $5.5 \mathrm{I}$ & $7.4 \mathrm{I}$ & 8.42 \\
40 & 4.78 & 8.68 & 8.75 \\
45 & 4 & 5.11 & 6.07 \\
\hline
\end{tabular}

Optimization of Feed to solvent ratio: The optimized temperature-time combination was used to carry out solvent extraction of lycopene from tomato pomace using Acetone: Ethyl acetate (T14) as the solvent system for the optimization of the feed to solvent ratio. The optimum feed to solvent ratio was selected on the basis of the highest lycopene content $(\mathrm{mg} / 100 \mathrm{~g})$ from the tomato pomace sample. The lycopene extract was analyzed for its concentration using UV-Vis spectroscopy technique. Lycopene content $(\mathrm{mg} / 100 \mathrm{~g})$ of four replications is reported in Table 3 . The data obtained was analyzed statistically. Among the three different feed to solvent ratios used (1:10, 1:20 and
1:30), solvent extraction carried out using 1:30 gave significantly higher lycopene content than the other feed to solvent ratios. The lycopene extracted, taking 1:30 as the feed to solvent ratio, using Acetone: Ethyl acetate (T14) as the solvent system and at $40^{\circ} \mathrm{C}$ for $5 \mathrm{~h}$ extraction condition had the highest lycopene content, i.e. $12.06 \mathrm{mg} / 100 \mathrm{~g}$. It may be due to the increase in the extraction power of solvent with the increase in the amount of solvent taken for the same amount of feed or sample taken. Therefore, 1:30 solvent ratio was selected for the characterization of lycopene and its bulk extraction for shelf life study. The optimum feed to solvent ratio obtained was in accordance with the feed to solvent ratio reported by Sadler. The optimization of the solvent extraction process for maximum recovery of lycopene from tomato pomace was carried out by selecting the suitable solvent system, optimum temperature-time combination and feed to solvent ratio, i.e., Acetone: Ethyl acetate, $40^{\circ} \mathrm{C}$ for $5 \mathrm{~h}$ and 1:30.

Characterization of the lycopene extract: The obtained extract was characterized for its purity, lycopene content, Refractive Index and colour value. All determinations were replicated thrice and average values of purity of the lycopene extract, lycopene content, Refractive index at $20^{\circ} \mathrm{C}$ were found to be $81.32 \%, 611.10 \mathrm{mg} / 100 \mathrm{~g}, 1.37604$ respectively and $L^{*} a^{*} b^{*}$ values were found to be $5.59,8.00,6.14$.

Storage Study of the lycopene extract: The storage study was carried out for 60 days and samples were analyzed for its lycopene content $(\mathrm{mg} / 100 \mathrm{~g})$ at 6 intervals and the values are reported in Table 4. The trend of lycopene content during the storage period at two different conditions is depicted graphically in Figure 2. From the Figure 2, it indicates that as the storage period increased, the lycopene content decreased for both the conditions of storage. The lycopene content decreased quite faster at $30^{\circ} \mathrm{C}$ storage as compared to at $-4^{\circ} \mathrm{C}$ temperature for a particular period of storage. The lycopene content almost remained same for the entire period of storage at $-4^{\circ} \mathrm{C}$. The effects of temperature and time of storage were significant at $5 \%$ level. The storage study results were in accordance with those reported by Akbari et al. ${ }^{14}$ The maximum lycopene content was obtained when the extract was fresh while the minimum lycopene content was obtained at the end of the storage of 60 days at $30^{\circ} \mathrm{C}$. This may due to the degradation of trans-lycopene in to cis-lycopene (isomerization). Light and heat disintegrate tomato tissue and can result in destruction of lycopene. From the results, it was observed that the storage of lycopene at $-4^{\circ} \mathrm{C}$ can retain maximum lycopene quality. 
Table 3 Effect of feed to solvent ratio on lycopene content

\begin{tabular}{lllllll}
\hline \multirow{2}{*}{ Code } & \multirow{2}{*}{ Feed to solvent ratio (w/v) } & \multicolumn{6}{c}{ Lycopene content $(\mathbf{m g} /$ / 00 g) } \\
\cline { 3 - 7 } & & LI & L2 & L3 & L4 & Mean \\
\hline FSI & $01: 10$ & 4.75 & 4.82 & 4.69 & 4.74 & 4.75 \\
FS2 & $01: 20$ & 9.1 & 9.14 & 9.23 & 9.17 & 9.16 \\
FS3 & $01: 30$ & 11.99 & 12.08 & 12.11 & 12.06 & 12.06 \\
\hline
\end{tabular}

Table 4: Changes in lycopene content in extract during storage.

\begin{tabular}{|c|c|c|}
\hline \multirow{2}{*}{ Storage period (days) } & \multicolumn{2}{|c|}{ Lycopene content $(\mathrm{mg} / \mathrm{l} 00 \mathrm{~g})$ at storage temperature } \\
\hline & $30^{\circ} \mathrm{C}$ & $-4^{\circ} \mathrm{C}$ \\
\hline 0 & $611.10(0)$ & $611.10(0)$ \\
\hline 7 & $535.89(|2.3|)$ & $611.03(0.01)$ \\
\hline 14 & $481.17(21.27)$ & $611.0(0.02)$ \\
\hline 21 & $454.33(25.65)$ & $608.13(0.49)$ \\
\hline 30 & $401.11(34.36)$ & $605.0(1.00)$ \\
\hline 45 & $342.46(44.0)$ & $601.11(1.63)$ \\
\hline 60 & $284.92(53.38)$ & $595.18(2.61)$ \\
\hline Sem & 1.858546 & 0.388909 \\
\hline$C D(0.05)$ & 5.73 & 1.19 \\
\hline CV (\%) & 0.73 & 0.11 \\
\hline
\end{tabular}

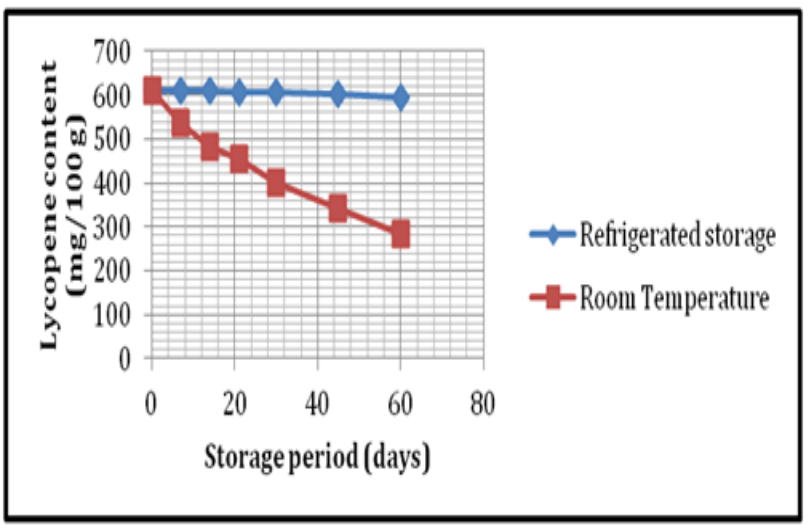

Figure 2 Changes in lycopene content during storage.

\section{Conclusion}

For efficient extraction of lycopene from tomato pomace by solvent extraction method can be done using Acetone: Ethyl acetate (1:1) as solvent system at $40^{\circ} \mathrm{C}$ for $5 \mathrm{~h}$ and $1: 30$ feed to solvent ratio. The lycopene content in the lycopene extract gradually decreased during the storage study of 60 days. The maximum being at the beginning of storage study, minimum on $60^{\text {th }}$ day at $30^{\circ} \mathrm{C}$ storage conditions.

\section{Acknowledgements}

None.

\section{Conflict of interest}

The author declares no conflict of interest.

\section{References}

1. Rao AV, Agarwal S. Role of antioxidant lycopene in cancer and heart disease. J Am Coll Nutr. 2000;19(5):563-569.

2. Vargas FD, Lopez OP. Chemicals and colorants as nutraceuticals. Natural colorants for food and nutraceuticals uses. Boca Raton, USA: Fla CRC Press; 2003. 257 p.

3. Hanson PM, Yang RY, Wu J, et al. Variation of antioxidant activity and antioxidants in tomato. J Amer Soc Hort Sci. 2004;129(5):704-711.

4. Sharma SK, Le Maguer M. Lycopene in tomatoes and tomato pulp fractions. Italian Journal of Food Science. 1996;8(2):107-113.

5. Potty V. By-products utilization can improve the economics of tomato industry. Processed food industry, Mysore, India: CFTRI; 2009.

6. Shi J, Maguer M. Stability of lycopene in tomato dehydration. Osmotic dehydration and vacuum impregnation applications in food industries. Boca Raton, USA: Fla CRC Press; 2001.

7. Sogi D, Bawa A. Studies on dehydration of tomato processing waste. Indian Food Packer. 1998;52(2):26.

8. Kaur D, Wani AA, Oberoi DP, et al. Effect of extraction conditions on lycopene extractions from tomato processing waste skin using surface response methodology. Food Chem. 2008;108(2):711-718. 
9. Clinton SK. Lycopene: chemistry, biology and implications for human health and disease. Nutr Rev. 1998;56(2 Pt 1):35-51.

10. Semedo M, Machado R, Marques MJ, et al. Recovery of carotenoids in the industrial process of tomato processing. Av Rovisco Pais, Portugal: Instituto Superior Técnico; 2012.

11. Barba AIO, Hurtado MC, Mata MCS, et al. Application of a UV-vis detection-HPLC method for a rapid determination of lycopene and $\beta$-carotene in vegetables (2006). Agris. 2013;95(2):328-336.
12. Lavecchia R, Zuorro A. Enhancement of lycopene extraction from tomato peels by enzymatic treatment. Chemical Engineering Transactions. 2008; 14:301.

13. Naviglio D, Pizzolongo F, Ferrara L, et al. Extraction of pure lycopene from industrial tomato waste in water using the extractor Naviglio ${ }$. Afr J Food Sci. 2008;2(2):37-44.

14. Akbari SH, Joshi DC, Bhatt HG, et al. Standardization of drying and extraction techniques for production of lycopene from tomato processing waste (pomace). IJGHC. 2014;3(2):468-473. 